\title{
ANALYSIS OF THE REFUNCTIONED MILLET HAMAM THROUGH SPACE SYNTAX
}

\author{
Ş. Ebru OKUYUCU \\ Afyon Kocatepe University, Turkey \\ ebruokuyucu@hotmail.com \\ https://orcid.org/0000-0001-9507-5467 \\ Gamze ÇOBAN \\ Afyon Kocatepe University, Turkey \\ a.gamzecoban@gmail.com \\ https://orcid.org/0000-0001-6524-3861
}

\begin{abstract}
Space syntax is a model that has been developed based on spatial formation characteristics. The theory of space syntax indicates a strong relationship between spaces and social structures. The concept of space syntax in this study served as a basis for the assessment of the new function displayed by the architectural structure named "Millet Hamamı (Public Hammam)" in Afyonkarahisar, Turkey. The spatial use of another architectural structure named "Kültür ve Semt Evi (Local House of Culture)" that was transformed from Millet Hamamı was analyzed in this study. The purpose of this paper is to constitute space organization of Cultural and District Centre, daily use of space, user movement, defining the relation between space and function, analysis of the spatial provision of the existing building-new function relationship. Graphs used in order to make analysis of the space formation and space organization corresponding to the new function of Millet Hamam which has been transformed into Cultural and District Centre constitute the whole set of techniques of the space syntax in the study. The face-to-face interviews performed with the users of the building contributed to the study. As a result of the analysis made through using numerical data, locations of the spaces belonging to refunctioned Cultural and District Centre within the building, the compatibility of all the spaces with their new functions, the usage potential of the spaces and the spatial experiences of the users have been interpreted with respect to existing building-new function scale. In the study, positive and negative outcomes have been evaluated in line with the spatial relations by discussing the spatial provision of the new functions in the Cultural and District Centre and suggestions have been made regarding use of the spaces. As a result of the study, it was stated that the correct choice of function in historical buildings that are planned to be re-functional is possible by analyzing the organization of spaces using the graf method and supporting the data obtained with the views of the building users. This study is important in terms of increasing the usage potential of spaces within a newly-functionalized building, which is different compared to other relevant studies.
\end{abstract}

Keywords: Space Syntax, Graph Method, Millet Hamam, Afyonkarahisar. 


\title{
YENIDEN İŞLEVLENDİRILMIŞ MILLLET HAMAMI'NIN MEKÂN DIZIM YÖNTEMIYLE ANALIZI
}

\begin{abstract}
$\ddot{O Z Z}$
Mekân Dizim analizi, mekânın biçimlenme özellikleri üzerine geliştirilmiş bir modeldir. Mekân dizim kuramı mekân ve sosyal yapı arasında güçlü bir bağ olduğunu ortaya koymuştur. Bu bağlamda mekân dizimi Afyonkarahisar'da bulunan Millet Hamamı'nın yeni işlevinin değerlendirilmesi için temel olmuştur. Çalışma kapsamında, Millet Hamamı'ndan dönüştürülen Kültür ve Semt Evi'nin mekân kullanımı analiz edilmiştir. Kültür ve Semt Evi'nin mekân örgütlenmesi, günlük alan kullanımı, kullanıcı hareketi, mekân fonksiyon ilişkisinin tanımlanması, mevcut bina-yeni işlev ilişkisinin mekânsal karşılığının analizi, çalışmanın ana çatkısını oluşturmuştur. Kültür ve Semt Evi'ne dönüştürülen Millet Hamamı'nın yeni işlevine karşılık gelen mekân örgütlenmesinin, mekânsal biçimlenmenin analizini yapabilmek için kullanılan graflar, çalışmada mekân diziminin teknikler bütününü oluşturmaktadır. Bununla birlikte, bina kullanıcılarıyla yapılan birebir görüşmeler çalışmaya katkı sağlamıştır. Sayısal veriler kullanılarak yapılan analizler sonucunda; yeniden işlevlendirilen Kültür ve Semt Evi'ne ait mekânların bina içindeki konumları, tüm mekânların yeni işlevleriyle olan uyumu, mekânların kullanım potansiyeli, kullanıcıların mekânsal deneyimleri; mevcut bina-yeni işlev ölçeğinde yorumlanmıştır. Çalışmada, Kültür ve Semt Evi'nde yeni işlevlerin mekân karşılıkları tartışılarak, mekânsal ilişkiler düzleminde pozitif ve negatif sonuçlar değerlendirilmiş ve mekânların kullanımına yönelik öneriler sunulmuştur. Çalışma sonucunda, yeniden işlevlendirilmesi planlanan tarihi binalarda doğru işlev seçiminin, graf yöntemiyle mekân örgütlenmesine odaklanarak ve bina kullanıcılarının görüşleriyle desteklenmesi ile mümkün olduğu belirtilmiştir. Konuya ilişkin yapılan çalışmalardan farklı olarak bu çalışma, yeniden işlevlendirilen tarihi bir binada, mekânların kullanım potansiyelinin arttırılması bağlamında önem taşımaktadır.
\end{abstract}

Anahtar Kelimeler: Mekân Dizimi, Graf Yöntemi, Millet Hamamı, Afyonkarahisar.

\section{INTRODUCTION}

A key is needed to reflect the abstract concepts while mentioning the artificial systems. This key that indicates the relationship between spatial organization models such as society, city or culture and social relationships is defined as syntax. Regardless of the scale, a space is not solely a representative result or byproduct of social structure. Spatial organization is a concept that also affects different dimensions. Accordingly, the relationship between social structure and space is mutual (Hillier \& Hanson, 1984). The space syntax method aims to analyze the spatial forms in a building structure, to assess a space and to perceive the socio-cultural meanings in the background. The space syntax that helps assess the spatial formations suggests that there is a direct relationship between spatial organization and social structure. It particularly analyzes the fields of movement and view for people, and reviews the potential of gathering them. The concept of space syntax focuses on the relationship between people and the spaces they live in. Different behavioral manners, habits or cultural meanings can be assigned as the spatial texture is separated into small fragments (Bafna, 2003). In simple terms, contrary to assessing through the plan, people do not recognize the entire structure when walking in a space. They perceive the space in small fragments which are combined in their brains. These fragments can be expressed concretely and in a perceivable manner in the space syntax analysis. According to Dursun and Sağlamer (2003), with the spatial system, the characteristic properties and knowledge of a society are transferred to the space, spatial fragments and spatial organization. Accordingly, indicators such as privacy, hierarchy, introversion, extroversion, all of which are related to the concept of space within the social context, can be assessed over the spaces. Space syntax method uses the mathematical codes of spatial models. Moreover, these codes are supported with the data such as spatial socio-cultural characteristics, social variables and user-related values. As a result of the indication of spatial analyses performed with the space syntax method through the graphs, information can be generated from a social, physical and technical context. The graph method is a mathematical analysis form consisting of spaces that are

Submit Date: 22.10.2020, Acceptance Date: 28.11.2020, DOI NO: 10.7456/11101100/015 
connected through topologic, geometric and traditional relationships (Baysal, 2015). Graphs are used within the "space syntax" analysis method as spatial analysis method.

\section{AIM OF SCOPE}

With the new function of Millet Hamamı that was transformed into Kültür ve Semt Evi, efforts were made to examine the relationships between the changing spaces through the space syntax method. Spaces within Kültuir ve Semt Evi such as the entrance, social areas, ateliers or exhibition areas were included in the study. The aim was i. to analyze the impact of the new function assigned to Millet Hamamı on spatial configuration and ii. to examine the relationship between indoor and outdoor space organization and social structure. The analysis was performed through the digital data obtained by using the graphs with space syntax method. Moreover, the plan scheme of Kültür ve Semt Evi was analyzed based on the total and mean depth figures, and integration values calculated through the graphs. Using the space syntax method, the spaces that are within Kültür ve Semt Evi and integrated with the building and the spaces used less could be specified. The data obtained from the analyses were associated with the assumptions from the verbal interviews conducted with the users of the building, and the spatial organization and relationships were interpreted.
\end{abstract}

According to Dursun (2007), the spatial syntax method was used in the studies analyzing the processes of the environments that shape the spatial configuration of the buildings with the same function. However, no studies indicating the use of this method within a historical building that was refunctionalized, that had a new function totally different to its current function, and that required spatial patterns were not found in the literature. The spatial syntax of the re-functionalized historical building in this study was performed through the graphs enabling an analytic assessment, which makes this study significant.

\title{
METHODOLOGY
}

In the study, the transformation of a building consisting of many different sized spaces, such as a bath, into a function that requires wide openness for educational and exhibition purposes, such as a cultural and District House, required the questioning of the use cases of new spaces. Assignment of new functions to the historical buildings that have lost their original function totally and sustainability of cultural assets contributes to the city from social, economic and cultural context. The social indicators of a specific location should be correctly coded to the spaces to ensure the functional sustainability of historical buildings, which will result in strengthening the relationship between buildings and new functions, increasing user satisfaction, and raising the usage and lifecycle of buildings. Lefebvre (1991) reviewed the question of how buildings were socially generated. He interpreted the concept of space as a term that reaches beyond the context of geometry or a free space. Lefebvre (1991) noted that the concept of space reflects a social generation process and that it is a complicated social structure consisting of social values and perceptions. The space syntax method where the relationship between users and space is considered important in the refunctioning of historical buildings that establish a connection with social values was selected as an instrument in this study. Accordingly, the interactions between space, new functions and experiences within Millet Hamamı that was transformed into Afyonkarahisar Kültür ve Semt Evi were analyzed through space syntax. According to Çil (2006), space syntax is used not only on the urban scale, but also for the purpose of reviewing the spatial organizations at different scales. Therefore, the graphs used in the spatial analysis scale regarding Kültür ve Semt Evi are believed to be the relevant factors for the following:

- $\quad$ Analyzing and planning the movement organization within the multi-functional Kültür ve Semt Evi,

- Understanding the urban impact of Kültür ve Semt Evi in terms of spatial organization,

- Perceiving the concepts of spatial privacy, control or social hierarchy from a social perspective,

- $\quad$ Examining the spaces within Kültür ve Semt Evi from the perspectives of introversion and extroversion. 


\section{SPACE SYNTAX AND GRAPH METHOD}

The space syntax analysis is based on the systems that are related to the discipline of philosophy which aims to explain the relationship between brain and outer world. The human form aims to explain the relationship between the concepts of function and space through the theoretical model structure. A particular language was developed for the organizations that could not be defined in the process of understanding the spatial formation in the space syntax analysis method (Gündoğdu \& Çıracı, 2006). The method has been made usable with the studies and designing practice performed globally. It has also been recently used to assess the buildings through designing styles by the users or designers. The literature of space syntax is related to configuration, explaining it in a relative manner. Hillier defined the configurational relationships in his book "Space is Machine" as follows: "The relationships arising from the mutual interaction between at least three elements is a simple complex". He claimed that perceptional understanding toward the concept of configuration contributed to the understanding toward the buildings and urban residences (Hillier, 1996, 1998).

The users have a connective or fragmenting impact on each other in the process of organizing regarding every space (Çil,2006). Hillier considered the definite and already-defined structure of the impact arising from the potential of physical spaces in forming a society. He noted that the impact was clear in the places that help form the spaces of effective social communication (Güç, 2010). "Measurability and integrity are two main space syntax analysis concepts that enable interpreting the relationship between the formal properties of a residence and its socio-cultural world. The movement and visibility reflect the parameters indicating the limit of the access a spatial configuration offers to the people in it" (Çil, 2006).

The analyses performed through the space syntax theory review the status of spaces in their entirety and the relationship with other spaces, rather than the spatial physical characteristics. The data to be obtained by the space syntax theory within the relationship between the concepts forming the entirety within a space are reflected as follows:

- $\quad$ Accessing the key part of spatial model and reflecting the variety within spatial organizations,

- $\quad$ Explaining the main concept through the other auxiliary elements (letters, letters, formula etc.),

- $\quad$ Displaying the status and relationships between these concepts,

- Explaining how these concepts combine and are transformed into an integrated structure (Şişman, 2015).

Space syntax methods mention the formal relationship in a part to whole manner and aim to formationrelated properties in a consistent, exact and measurable style. These methods utilize the abstractness for the use of graphic displays regarding the formation-related properties. They collectively use the concept of intuitive eye and analytic brain, determining the hidden pattern. Moreover, they reveal the genotypical properties of spatial patterns (Hillier \& Hanson, 1997).

During 1980s, the space syntax method proposed by Hillier and Hanson reflects the relationships between spaces through graphs in a mathematical form, and it enables the analysis of these relationships in this regard (Baysal, 2015). This method can define and analyze the relationship between the internal and external space organization and social structures in the discipline of architecture. The concept of space syntax reflects that the rules and restrictions constituting the space should be understood first to understand the spatial form. This method contributes to the efforts to understand the interaction between designing characteristics and objective, and social restrictions and formal probabilities better (Hillier \& Hanson, 1984). Another important aspect of this approach is its concrete expression and analysis of the space within people's thoughts. The spaces are divided into fragments through the space syntax method, transformed into maps and graphs, and the first step for analyses is formed. The objective of space syntax method is to explain the relationship between the surfaces, sides, areas, passages and the entire space as observed by the people moving in that space (Çil, 2006). According to David Seamon, the greatest characteristic of space syntax that differs the concept from other analytic approaches is that its

Submit Date: 22.10.2020, Acceptance Date: 28.11.2020, DOI NO: 10.7456/11101100/015

Research Article - This article was checked by iThenticate

Copyright $($ ) The Turkish Online Journal of Design, Art and Communication 
methods used in describing the space focus on "people's spatial experiences" (Seamon, 2007). Graphs that are the analysis instruments of space syntax method reflect the manners of organization regarding the spatial system within the buildings and functional relationships in this regard. Graphs aim to display the spatial order of importance within the functional system and users' relationships based on social attitude in a "digital" form (Steadman, 1983; Hillier \& Hanson, 1984). Graphs are used in the architectural functions, building programming, analysis of building morphology, and typological classification of functional buildings (Yildırım, 2002). Graphs are the clusters of dots formed by connecting the lines to one another. Dots reflect the spaces while lines indicate the connection between two spaces (Levin, 1964). Each space is shown as a vertex. Indoor spaces are displayed using a blank circle while outdoor spaces are shown using “+” (Figure 1) (Baysal, 2015).

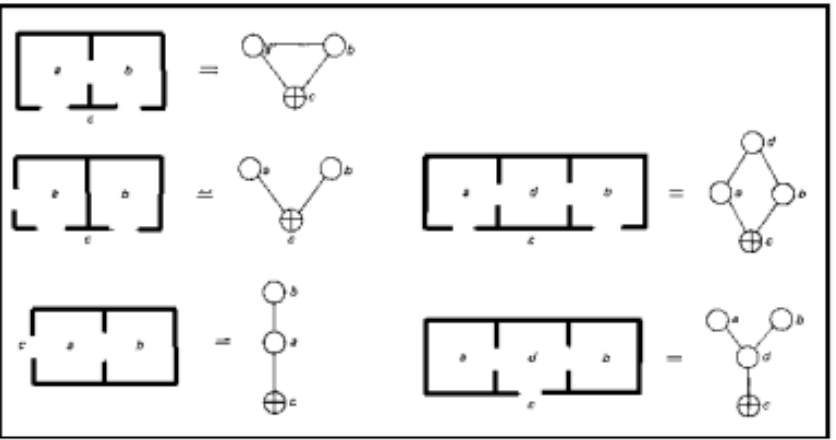

Figure 1. Indication of different examples with graph method

Resource: Hillier \& Hanson (1984)

Graph method is a mathematical analysis form consisting of spaces that are connected to each other through topological, geometric and traditional methods (Hacihasanoğlu, 2007).

The rules regarding the graphs:

- The length of the lines connecting the spaces to one another is not important in the formation of graphs.

- The angles of the lines in a graph are not important.

- $\quad$ The type or size of the spaces is not important.

- A space should always be present in a graph for the connection of two lines; these lines cannot intersect without a space (Levin, 1964).

The space before the entrance is selected as the initial space while forming the graph. Other spaces are added as the layers of depth to this space. These layers represent the number of spaces passed to access a space in this system (Figure 2) (Y1ldırım, 2002).

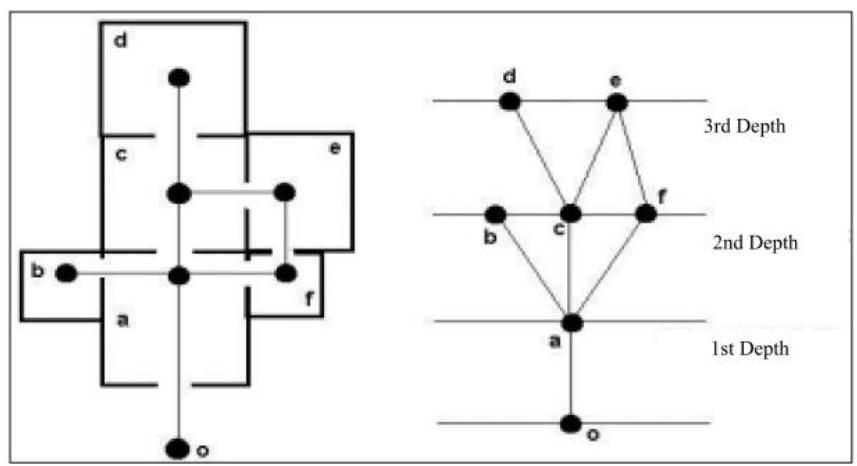

Figure 2. Plan scheme of a space and its graph organized according to the root space

Resource: Hillier \& Hanson (1984)

The analysis instruments used while utilizing the space syntax method are as follows: 
Mean Depth Value: The concept of depth is related to the number of spaces passed to access a space in this system. The relationship between one space and the other is reflected through a value and displayed on a configured graph (e.g. First-degree depth or second-degree depth). This order is created based on the number of spaces to be passed to reach each space (Şanll, 2009, Hillier \& Hanson, 1984).

Variable of depth: It helps us access the privacy-related information within the system. The analyses question the deepest space, and by whom and for what this space is used. The mean depth figure is found by dividing the total depth value into the figure that is one less than the number of spaces ( $M d=\Sigma d /(k-1)$ (Şanll, 2009; Hillier \& Hanson, 1984).

Integration value / Relative asymmetry $(R a)$ : "The mathematical expression of the relative depth of a space compared to other spaces in a graph reflects the 'relative asymmetry' figure of that space. This figure indicates whether that space has a combining aspect within the configuration" (Şanl1, 2009), and it is used to find the space that has the most intensive relationship with other sections in a space ( $R a=\frac{2 \cdot(M d-1)}{k-2}$

) (Şanl1, 2009, Hillier \& Hanson, 1984). The integration value is separately calculated for every space. This value is always between 0 and 1 , and the maximum integration is seen in the values that are closer to 0 (Y1ldirım, 2002). The spaces with high integration value are defined as the spaces with high visuality and permeability, and as the points of discharge. These points are where the social interaction is intensive. However, the spaces where social interaction is at a lower level have deep and low integration (Figure 3) (Ünlü et al., 2001).

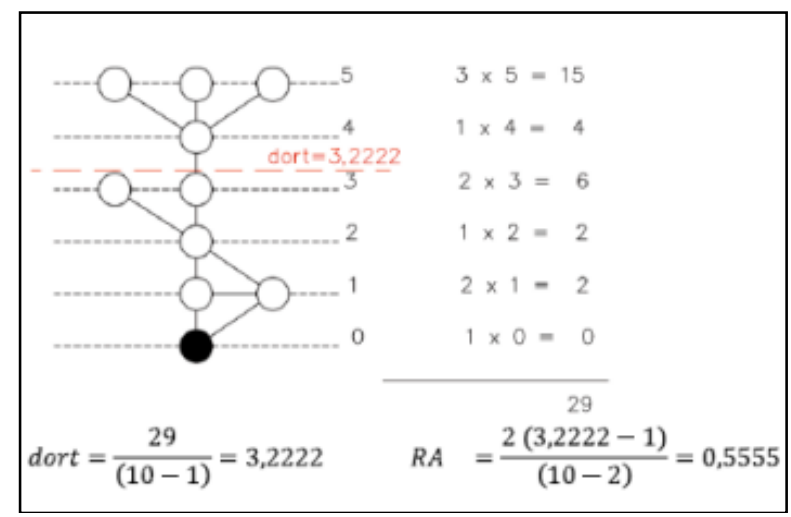

Figure 3. Calculating average depth and integration value in a transition graph

Resource: Şanlı (2009)

Assumptions regarding a space and the social life forming that space can be made through the space syntax, which is different compared to the spatial assessments conducted through formal or typological analyses. Accordingly, buildings reflect a social meaning through their own images and plans. This study took the claim of Hillier and Hanson (1984) that space syntax theory reflects the social relationships with the relation to the spatial physical relationships into account. The spatial organization scheme was transferred to the graphs to analyze the codes of spatial formations regarding the refunctionalized Kültür ve Semt Evi.

\section{MILLET HAMAM}

The cultural asset called Millet (Gavur) Hamamı in Afyonkarahisar is present on a traditional, broad texture within the urban center. The location of Millet Hamamı is limited and protected. Believed to have been constructed in the second half of the 17th century during the Ottoman Era, Millet Hamam1 served until 1980s. The historical building has been destroyed in time and registered as an historical asset to be preserved. The ownership of this building has been assigned as a registered cultural asset to the Municipality of Afyonkarahisar, and the building was restored upon the decision of Restoration Committee on 20.12.2003. Re-functionalizing the building in a manner to meet the social and cultural 
needs of the people in Afyonkarahisar was deemed appropriate. Following this process, the name of the building was changed to "Kültür ve Semt Evi" in 09.11.2005 (Aydın \& Okuyucu, 2009). The visuals regarding Millet Hamamı and Kültür ve Semt Evi, and the spatial organization was presented in the table (Table 1)

Table 1. Millet Hamam Images

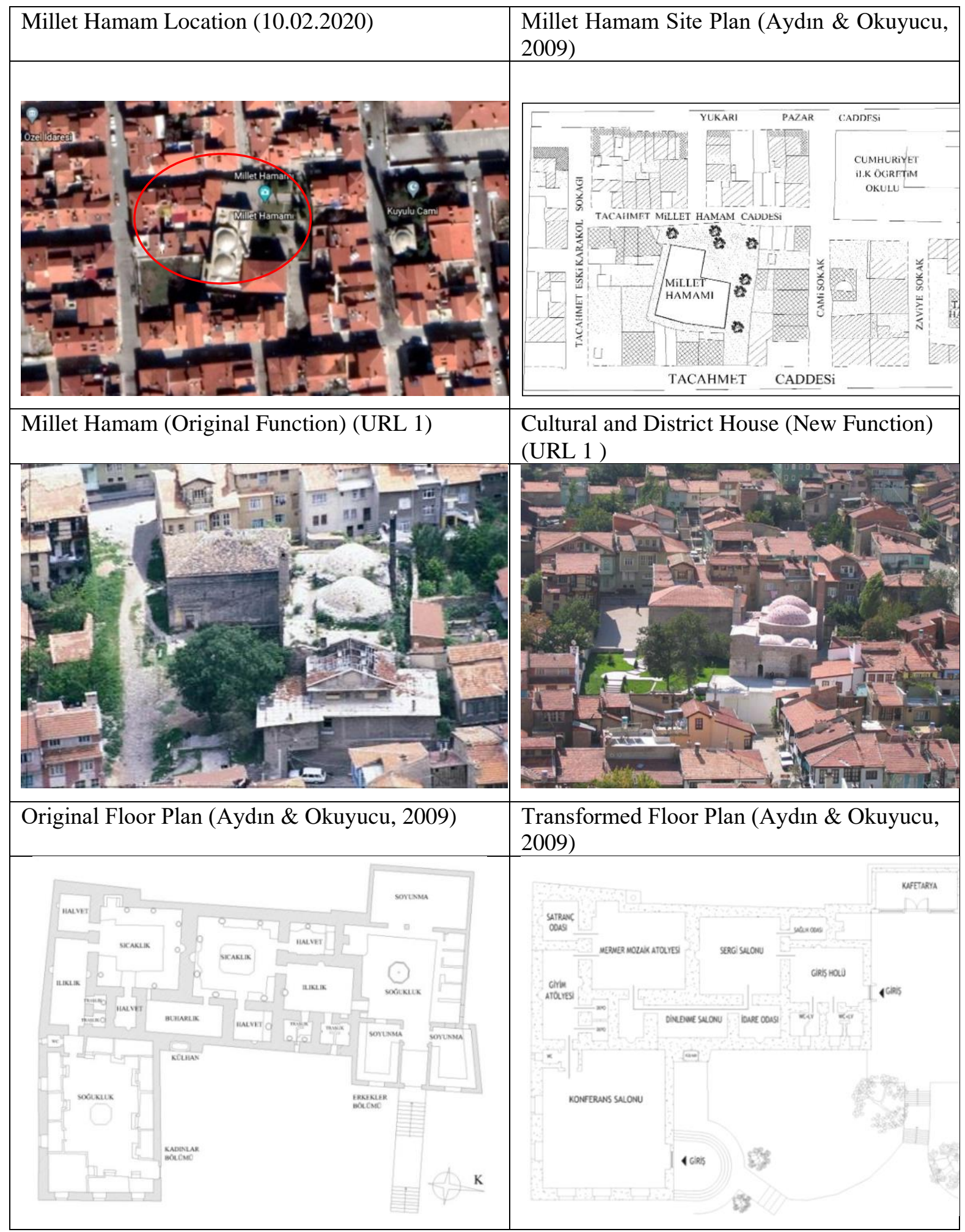


Millet (Gavur) Hamamı was built in a form to serve both genders (as hammam for men and women). The areas of caldarium, privacy, tepidarium and frigidarium which are present in every hammam were also present, and there were relationships between the spaces that were related to one another and that had different sizes. Following the entrance, the spaces were respectively as follows: tepidarium, caldarium, privacy and steam room. This spatial organization did not change for the hammam for men and women. The authentic status of the hammam was distorted with the frigidarium in the section for women which is noted to have been added in 1911 on the cornerstone. An architectural form that was similar to the one constructed on the south was built on the north as a frigidarium for men. This architectural section added later to the male division was removed during the restoration phase, and only the pool was left before the entrance. Millet Hamamı serves around the Castle of Afyonkarahisar under the name "Kültür ve Semt Evi" in the present time. Serving the women and students particularly, Kültür ve Semt Evi offers courses in various fields such as cultural and personal development, medicine, foreign language, art, mosaic marble production or jewelry designing. The platform prepared before the entrances on the green area around the hammam in previous years was used as a podium in jazz festivals (Aydin \& Okuyucu, 2009).

The sizes of all spaces in the hammam are different, and the spaces with a greater size are used for exhibitions and training-related purposes. The most commonly-used spaces of the hammam included the caldarium and tepidarium for women and caldarium for men. These sections are now used as ateliers in their new functions. The smaller spaces in the hammam as cells have been organized as chess, management and medical rooms in their new functions. The conferences and similar activities are performed in the lately-added section frigidarium in its new function within the hammam for women. The frigidarium section for men was removed, and a space that is now used as a cafeteria in its new function was organized. The original spaces within the plan scheme of Millet Hamami were reorganized based on the spaces needed in terms of new Kültür ve Semt Evi. The spatial changes within the plane of Original-Transformed Plan are presented in the figure ( Figure 4).

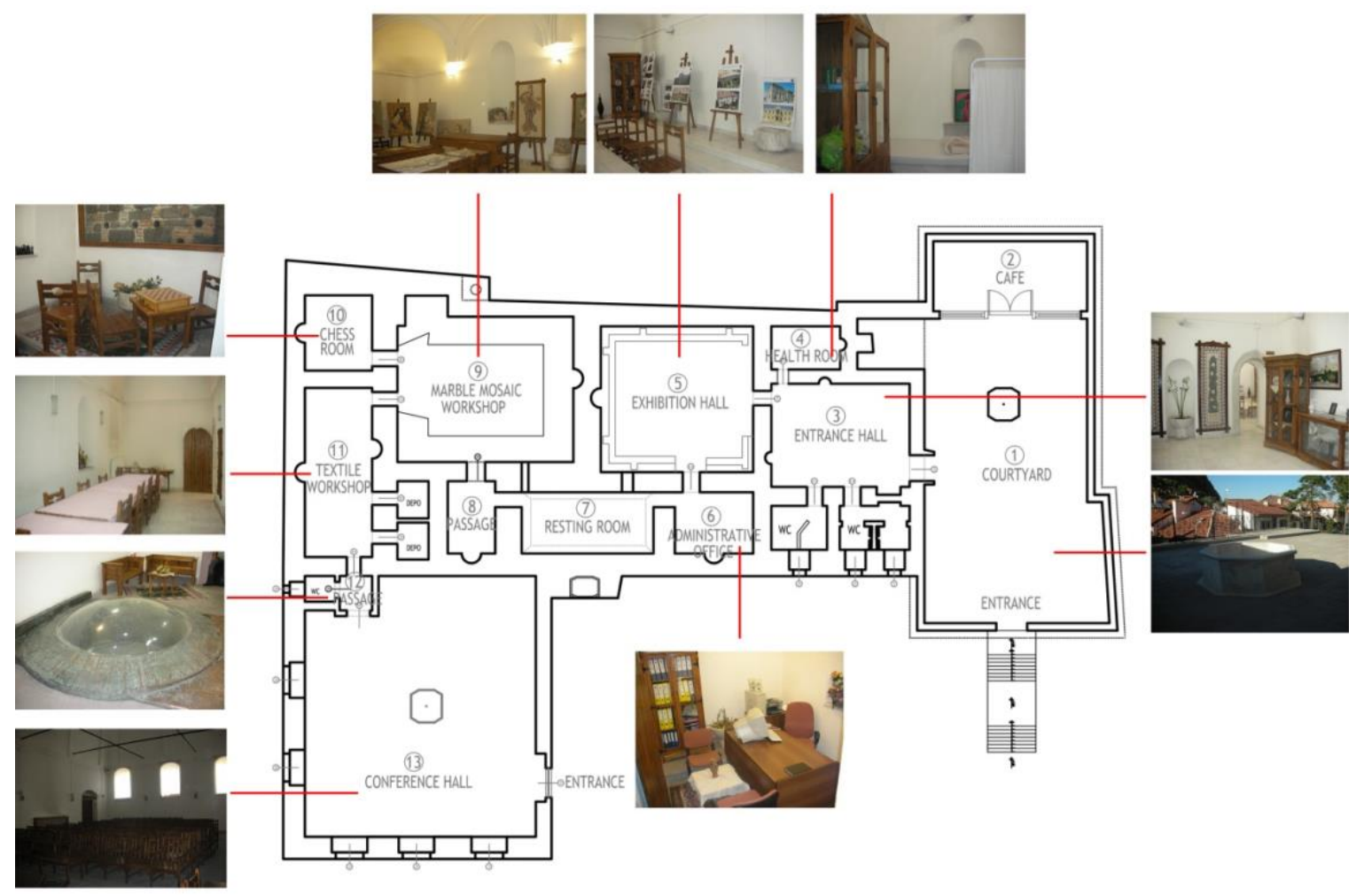

Figure 4. Cultural and District House Images

Resource: Archive 


\section{Transferring the Spatial Organization of Kültür Ve Semt Evi into Graphs}

Separate graph schemes were formed for 13 different spaces in the building including the outdoor area in this study in which space syntax method was used. The spaces were ordered by the degree regarding the depth of the initial space to these spaces. Following the ordering, the total depth value was calculated based on the number of spaces. The mean depth figure was found by dividing the total depth value into the figure that is one less than the number of spaces. The integration value reflecting the integrity within a building was calculated by using this formula.

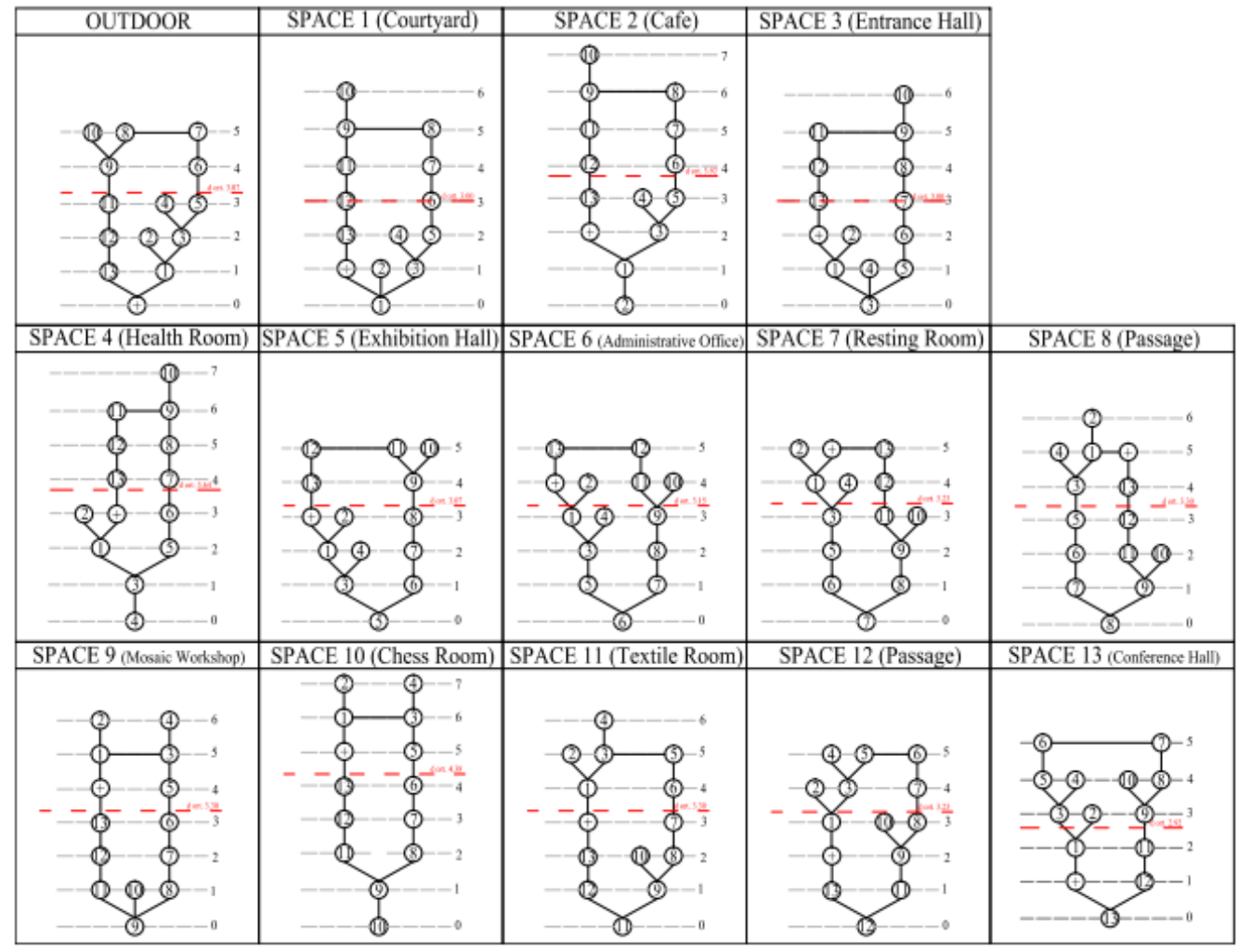

Figure 5. Graphs Of Cultural and District House

The total depth, mean depth and integration values achieved at the end of the analyses conducted by using the graphs are presented in the table below (Table 2).

Table 2. Numerical data obtained through graphs belonging to the Cultural and District House spaces

\begin{tabular}{|c|c|c|c|c|}
\hline & Space & Total Depth & Average Depth & Integration Value \\
\hline Outdoor & Outdoor & 40 & 3.07 & 0,34 \\
\hline Space 1 & Courtyard & $\mathbf{3 9}$ & $\mathbf{3 . 0 0}$ & $\mathbf{0 , 3 3}$ \\
\hline Space 2 & Cafe & 51 & 3.92 & 0.48 \\
\hline Space 3 & EntranceHall & $\mathbf{3 9}$ & $\mathbf{3 . 0 0}$ & $\mathbf{0 . 3 3}$ \\
\hline Space 4 & HealthRoom & $\mathbf{5 1}$ & $\mathbf{3 . 9 2}$ & $\mathbf{0 . 4 8}$ \\
\hline Space 5 & ExhibitionHall & 40 & 3.07 & 0.34 \\
\hline Space 6 & Administrative Office & 41 & 3.15 & 0.35 \\
\hline Space 7 & RestingRomm & 42 & 3.23 & 0.37 \\
\hline Space 8 & Passage & 43 & 3.30 & 0.38 \\
\hline Space 9 & MarbleMosaic & 43 & 3.30 & 0.38 \\
\hline Space 10 & Workshop & & $\mathbf{4 . 2 3}$ & $\mathbf{0 . 5 3}$ \\
\hline Space 11 & TextileRoom & 43 & 3.30 & 0.38 \\
\hline Space 12 & Passage & 42 & 3.23 & 0.37 \\
\hline
\end{tabular}




\begin{tabular}{|l|l|l|l|l|}
\hline Space 13 & Conference Hall & 41 & 3.15 & 0.35 \\
\hline
\end{tabular}

\section{Users' Thoughts on the Spatial Organization of Kültür Ve Semt Evi}

According to Hillier (1996), a building is basically shaped in two different directions. These shapes take an inclination from the physical to spatial form and from the physical to socio-cultural function. The objective figures of physical environment that can be measured through the space syntax method of the physical environment are in an interaction with the subjective values and personal experiences reflected through the meeting method.

It is important to determine the spatial relationships utilized to locate the public buildings that increase the probability of gathering people with different functions. The study searched an answer for the following question: "Why is it important to determine the areas or spaces that have the potential of gathering people in a building?" The digital figures regarding the configuration of the spaces within Kültür ve Semt Evi, the relationship between these spaces and relevant functional concepts were revealed using the space syntax. The use cases of the existing spaces of the building in the new function, the positive and negative aspects of the new spaces, culture and Neighborhood House were determined by interviews with users who received direct services. Interviews were conducted with the users to analyze the relationship between the spatial formation of the building and social structure, and to support the method of space syntax method. These interviews made contributions to find the conceptual equivalences of the digital data obtained with the graphs on the spatial scale.

Within the face-to-face interviews performed for the analysis of the relationship between the indoor and outdoor spatial configuration and social structure;

- $\quad$ The questions asked in regard to the usage potential of the spaces defined with the functions of Kültür ve Semt Evi, and

- convenience of the locations of spaces meeting the requirements of the functions regarding Kültür ve Semt Evi were directed to the users of the building (trainee, trainers and management personnel).

Within the scope of the study, 15 people consisting of users of the building were asked the following questions with the face-to-face interviews and the answers are stated in the table according to the number of people.

Table 3. Questions asked in face-to-face interviews

\begin{tabular}{|c|c|c|c|c|c|c|c|c|c|c|c|c|}
\hline Questions & 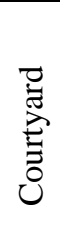 & $\underbrace{\frac{\pi}{\pi}}_{\tilde{J}}$ & 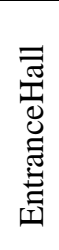 & 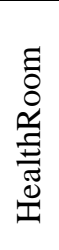 & 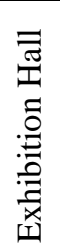 & 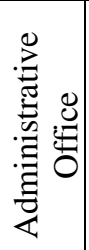 & 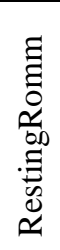 & 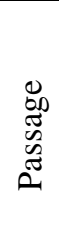 & 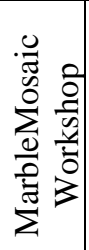 & 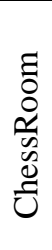 & 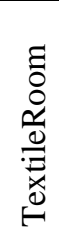 & 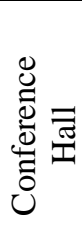 \\
\hline $\begin{array}{l}\text { Which/which are the places you use } \\
\text { most often in the building? }\end{array}$ & 11 & & 4 & & & & & & & & & \\
\hline $\begin{array}{l}\text { Which/which are the rarest places } \\
\text { you use in the building? }\end{array}$ & & & & 9 & & & & & & 6 & & \\
\hline $\begin{array}{l}\text { Which/which are the places where } \\
\text { you spend the most time in the } \\
\text { building? }\end{array}$ & & & & & 6 & & & & 3 & & 2 & 4 \\
\hline $\begin{array}{l}\text { Which/which are the places where } \\
\text { you spend the least time in the } \\
\text { building? }\end{array}$ & & & & 8 & & 3 & 4 & & & & & \\
\hline $\begin{array}{l}\text { Is there a place in the building that } \\
\text { you want to be in a different place? }\end{array}$ & & 7 & & & & 2 & 6 & & & & & \\
\hline
\end{tabular}

Submit Date: 22.10.2020, Acceptance Date: 28.11.2020, DOI NO: 10.7456/11101100/015

Research Article - This article was checked by iThenticate 


\section{Assessment of the Analysis Results}

The integration value that digitally indicates the intensity of usage regarding the buildings affects the movement within a building and people's rate of meeting. Therefore, the integration value is an important figure in determining the social interaction between users and spaces. The analyses performed in line with the data obtained from the graphs and interviews were used for the re-functionalization of Millet Hamamı as Kültür ve Semt Evi as follows:

(i) According to the graph analysis;

- The space where the integration value was closest to zero and integration value was the highest was Space 1 (Yard).

- $\quad$ The space where the integration value was closest to zero and integration value was the highest after Space 1 was Space 3 (Entrance Hall).

- $\quad$ The space where the integration value was closest to one and integration value was the lowest was Space 10 (Chess Room).

- $\quad$ The space where the integration value was closest to one and integration value was the lowest after Space 10 was Space 4 (Medical Room).

The high integration value of the yard (Ra: 0.33 ) indicated that the access to the space was easy and direct, and that it matched the functional aspect of the space.

The low integration value of the cafeteria $(\mathrm{Ra}: 0,48)$ indicated that it did not match the functional aspect of the space. Cafeteria should be a place where people intensively gather. However, the integration value of the cafeteria that was close to one indicated that the location of the space within the building was not correct.

The high integration value of the entrance hall (Ra: 0.33) indicated that the access to the space was easy, and that it matched the functional aspect of the space.

The low integration and high depth value of the medical room (Ra:0.48) indicated scarce movement within the building. Accordingly, the privacy required by the functional aspect of the medical room was clearly ensured within the space.

The high integration value of the exhibition hall (Ra:0.48) indicated high social interaction. The potential of gathering people within the functional aspect of exhibition hall was clear within this space.

The integration value of the control point (Ra:0.48) was high, while its depth value was low. These values indicated that there was an easy and direct access to the space, and they did not match the functional aspect within the building. Accordingly, the depth value of the control point was low within the building, and the control point itself had a low rate of movement, indicating it should be at a more isolated location.

The high integration value of the recreation room (Ra:0.37) indicated that it matched high social interaction. Due to the function of the recreation room, the depth value should be high, and the room should be at a more isolated location within the building.

The high integration value of the passage (Ra: 0.38) indicated easy and direct access. These values matched the functional aspect of the space.

The high integration value of the marble mosaic atelier (Ra: 0.38 ) indicated that it matched the functional aspect of the space. Moreover, the social interaction rate was high in the atelier, and the location of the space within the building suited the function.

The integration value of the chess room (Ra:0.53) was low, while its depth value was high. These values indicated scarce movement within the space, and they did not match the functional aspect within the space. Accordingly, low accessibility value of the space indicated correct position within the building as per the spatial function.

The integration value of the clothing atelier (Ra:0.38) was high, while its depth value was low, indicating that they matched the functional aspect within the space. Accordingly, the location of the atelier ensuring passage between the spaces, and its property of being accessible indicated that it matched the spatial function here. 
The integration value of the passage (Ra:0.37) was high, while its depth value was low. These values indicate that the rate of movement was high within the space, that the access was easy and direct, and that they matched the functional aspect of the space.

High integration and low depth values of the conference hall $(\mathrm{Ra}: 0,35)$ indicated that space matched with its functional equivalent. Values regarding the conference hall indicated that space was reachable and met the functional necessities.

(ii) The deductions below were made as a result of the face-to-face interviews with users.

- $\quad$ Spaces intensively used within the building included the exhibition hall, marble mosaic atelier, clothing atelier, and conference hall.

- $\quad$ The spaces where people were extensively active were yards, entrance hall, control point, and recreation room.

- $\quad$ Spaces that were not intensively used within the building were the chess room and medical room.

- The location of the control point and recreation room had a very intense circulation, which was negatively evaluated by the users.

- $\quad$ The cafeteria's location that was outside of the building was negatively evaluated by the users.

- Interviews with the users revealed that spatial integration was related to the observed actions. An ever-increasing relationship was found in more integrated areas.

- User comments revealed that the spaces of yard and entrance hall in which the frequency of usage was high were within the main vertex point.

\section{CONCLUSION}

In this study, a proper base was established to examine the configuration of physical space and experience-based relationships during the re-functionalizing of historical buildings. Quantitative data acquired from the analyses of Kültür ve Semt revealed that;

- Spaces with the highest integration value were the yard and entrance hall that established a connection with other spaces the most. In this context, spaces were found to match their functional aspects.

- The building had two entrances, which caused plan type to be more compact and depth value to be lower. While the depth value decreased, the value of integration increased, which positively affected the accessibility of the spaces. The depth value reflected the accessibility of the space. The building had an inversely-proportional relationship to its integration value, which indicates that the analysis is accurate.

- As a result of the graph analysis and user interviews, locations of the cafeteria, control room and recreation room did match the functional aspect of the space. More accessible location of cafeteria is thought to be better in terms of the harmony between the current building and new function.

- The control room should have an autonomous structure; thus, it should be located in an isolated area within the building.

- The recreation room should be in a less accessible location.

The space syntax method used in this study contributed to the efforts of transferring the theoretical information into the process of analyzing the configuration between the new function-spaces of the historical building. A bridge was founded between the research and analysis, which constituted the essence of 'evidence-based designing'. The space syntax method helped assess the historical building not only as a physical object, but also as a 'living organism' within the process of re-functionalization. Before re-functionalizing the historical buildings, the space syntax should be performed through the graphs, and data-based analysis of spatial configuration should be performed. This analysis will provide data about how the movement is to be organized for the living spaces. Moreover, assumptions can be made in terms of analyzing the relationship between the organization of physical space and culture (in the context of both daily life and identity). 
In conclusion, analysis of the space syntax through the graphs contributes to the re-functionalization of historical buildings and formation of spatial organizations. The graph method helped convert the digital results regarding the detection of spatial acts and concepts into the verbal data in the context of the harmony between the new and current buildings. The spatial organization analysis of the historical buildings to be re-functionalized should be conducted through the graph method. Supporting the data with the users' ideas is believed to be important. Defining the correct function begins with assessing the space properly in the process of re-functionalizing a historical building.

\section{REFERENCES}

Aydın, D. ve Okuyucu, S. E. (2009), "Yeniden Kullanıma Adaptasyon ve Sosyo-Kültürel Sürdürülebilirlik Bağlamında Afyonkarahisar Millet Hamamının Değerlendirilmesi”, Megaron, Cilt: 4, Say1: 1, pp.1-14.

Bafna, S. (2003), "Space Syntax, A Brief Introduction To Its Logic And Analytic Techniques", Enrironment and Behaviour, Vol 35, no.1, pp. 17-29.

Baysal, M. (2015), “Ankara'da Apartmanlar Ve Kapal1-Güvenlikli Toplu Konutlar Mekânsal Konfigürasyonu Sentaktik Analizi”, Yüksek Lisans Tezi, Gazi Üniversitesi Fen Bilimleri Enstitüsü, Ankara, pp.23.

Çil, E. (2006), "Bir Kent Okuma Aracı Olarak Mekân Dizim Analizinin Kuramsal ve Yöntemsel Tartı̧̧ması", Megaron, Cilt 1,Say6 4, pp.218-233.

Dursun, P. (2007), "Space Syntax in Architectural Design", Proceedings of the 6th International Space Syntax Symposium, No:056, İstanbul.

Dursun, P. and Sağlamer, G. (2003), "Spatial Analysis of Different Home Environments in the City of Trabzon”, 4th International Space Syntax Symposium, Londra, pp. 1-18.

Güç, B. (2010), "Hastane Dolaşım Mekânlarının Kullanıcı Üzerindeki Etkileri: Süleyman Demirel Üniversitesi Hastane Örneği”, Doktora Tezi, Karadeniz Teknik Üniversitesi Fen Bilimleri Enstitüsü, Trabzon.

Gündoğdu, M. ve Çıracı, H. (2006), "Galata-Pera mekânsal biçimlenme özellikleri ile arazi kullanımı”, İtü dergisi /A mimarlık, Planlama, Tasarım, pp.157-166.

Hacıhasanoğlu, O. (2007), "Mimarlıkta Biçimbilimsel Çalışmalar", İstanbul Teknik Üniversitesi Mimarlık Fakültesi Lisans Programı Seçmeli Ders Notları, İstanbul.

Hillier, B. (1996), Space The Machine, A Configuratiol Theory Of Architecture.

Hillier, B. (1998), “A Note On TheIntuiting Of Form: Three Issues In The Theory Of Design”, Environment and Planning B. 25th Anniverseary Issue, pp. 37-40.

Hillier, B. and Hanson, J. (1984), The Social Logic of Space, Cambridge University Press, pp. 147-149.

Hillier, B. and Hanson, J. (1997), "The Reasoning Art: or the Need for an Analytical Theory of Architecture", Proceedings of the 1st Space Syntax International Symposium, London.

Lefebvre. H, (1991), The production of space, Oxford, UK; Cambridge.

Levin. P. H, (1964), "Use of Graphs to Decide the Optimum Layout of Buildings", The Architects Journal, Liverpool.

Seamon, D. (2007), 6th International Space Syntax Congress Speeches, Istanbul.

Steadman, J., P. (1983), Architectural Morphology. An Introduction to the Geometry of Building Plans, London: Pion. U.K.

Şanlı, S. (2009) “Bir Mimara Ait Konut Tasarımlarının Mekân Sentaksı Yöntemiyle Analizi”, Doktora Tezi, İstanbul Teknik Üniversitesi Fen Bilimleri Enstitüsü, İstanbul, pp.12, 15, 20. 
Şişman, M. (2015), "Mekân Dizim Yönteminin Bir Mimari Tasarım Aracı Olarak Kullanılması Üzerine Bir Deneme", Yüksek Lisans Tezi, İstanbul Teknik Üniversitesi Fen Bilimleri Enstitüsü, İstanbul.

Ünlü, A., Edgü, E., Özden, T., Özener, O., (2001), “Axial Lines and Crime Relationship in Central Neighbourhoods", in J. Peponis, J. Wineman, S. Bafna (Eds.), Proceedings of 3rd. Internetional Symposium on Space Syntax, USA: College of Architecture, Georgia Instute of Technology, Atlanta.

Yıldırım, M., T. (2002), "Bina Fonksiyonu-Bina Biçimi İlişkisinde Çizge Teorisi Kullanımı İle Veri Eldesi”, Doktora Tezi, İstanbul Teknik Üniversitesi Fen Bilimleri Enstitiusü, İstanbul, pp. 100-102, 106, 108, 118, 121-124, 144-146, 149.

URL 1: https://www.visitafyon.org/sayfa-510-millet-hamami-afyonkarahisar.html 